\title{
Market and Financial Analysis of General Islamic D-Class Hospital Establishment in Karangmojo Gunungkidul
}

\author{
Munifah Ashlihati,* Firman Pribadi**
}

*M Author Correspondence: moon.ifah@gmail.com

* Master of Hospital Management, Postgraduate Program, Universitas Muhammadiyah Yogyakarta, Bantul, Indonesia

** Master of Hospital Management, Postgraduate Program, Universitas Muhammadiyah Yogyakarta, Bantul, Indonesia

I N D E X I N G

Keywords:

Feasibility study;

Market analysis;

Financial analysis;

Kata kunci:

Studi Kelayakan;

Analisis Pasar;

Analisis Keuangan:

\begin{abstract}
A B S T R AC T
This study aims to analyze the market potential and financial feasibility of the General Islamic Dclass Hospital establishment with a capacity of 100 beds in Karangmojo Gunungkidul. This was quantitative descriptive design with a feasibility study approach. The research was conducted in Karangmojo Subdistrict, Gunungkidul. The data used are primary data through filling in questionnaires, then secondary data from the health department of Gunungkidul Regency. The results of market analysis showed that there were problems with hospital services faced by respondents in the form of slow service (33\%), 39\% of respondents felt doctors were lacking in providing explanations or education, most $(96.76 \%)$ residents of Gunungkidul Regency were Moslems, The expectation of the community in the form of Islamic services is quite large (31\%), it will be answered by professional and Islamic Islamic hospital services. The financial analysis obtained a value of 1) NPV $=$ Rp.9,983,868,526.00; 2) IRR = 12.88\%; 3) PI = 1.3193 times; 4) PP = 8 years 4 months; and ARR $=10.49 \%$. Based on these results it can be concluded that In Karangmojo sub-district, Gunungkidul Regency, an Islamic hospital with 100 beds is feasible to be established from a review of market and financial aspects.
\end{abstract}

Penelitian ini bertujuan untuk Mengetahui potensi pasar dan kelayakan keuangan terhadap rencana pendirian Rumah Sakit Umum Islam kelas D dengan kapasaitas 100 TT (tempat tidur) di Karangmojo Gunungkidul. Desain penelitian ini adalah deskriptif kuantitatif dengan pendekatan studi kelayakan. Penelitian dilakukan di Kecamatan Karangmojo, Gunungkidul. Data yang digunakan adalah data primer melalui pengisian kuesioner, serta data sekunder dari dinas kesehatan Kabupaten Gunungkidul. Hasil analisis pasar menunjukkan adanya masalah pelayanan rumah sakit yang dihadapi responden berupa pelayanan yang lambat (33\%), sebanyak 39\% responden merasa dokter kurang dalam memberikan penjelasan atau edukasi, sebagian besar (96,76\%) penduduk Kabupaten Gunungkidul merupakan pemeluk Agama Islam, Harapan masyarakat berupa pelayanan yang Islami cukup besar yaitu 31\%, maka akan terjawab dengan pelayanan rumah sakit Islam yang professional dan Islami. Adapun analisis keuangan diperoleh nilai 1) $N P V=R p .9 .983 .868 .526,00$; 2) IRR = 12,88\%; 3) $P I=1,3193$ kali; 4) $P P=8$ tahun 4 bulan; dan ARR = 10,49\%. Berdasarkan hasil ini dapat disimpulkan bahwa di kecamatan Karangmojo Kabupaten Gunungkidul layak didirikan.

(C) 2019 JMMR. All rights reserved

Article history: Received 5 Feb 2017; Revised 15 Sept 2017; Accepted 25 Okt 2017

\section{INRTODUCTION}

Gunungkidul Regency is one part of the Special Region of Yogyakarta (DIY). The area of Gunungkidul Regency is $1,485.36 \mathrm{~km} 2$ or $46.63 \%$ of the area of the DIY Government. Gunungkidul Regency in 2015 had a population of 704,206 people, consisting of 340,531 men and 363,495 women. The average population density in Gunungkidul Regency is 473.9 people $/ \mathrm{km}^{2}$.

Religion adopted by residents in Gunungkidul Regency consists of Islam, Christianity, Catholicism, Hinduism and Buddhism. The religion adhered to by the majority of the population is Islam (96.76\%) followed by Christians (1.53\%) and Catholics (1.28\%).

Life expectancy is one indicator of public health and the Human Development Index (HDI) in Gunungkidul Regency in 2015 of $73.69 \%$. Average Life Expectancy of Gunungkidul resident's shows a number below the DIY province average but, still relatively high and quite good when compared to the National Life Expectancy average in Indonesia.

Individual and group health degrees that also reflect the health status of the community have not been optimally 
achieved. This is indicated by the high maternal mortality rate in 2016, which were 5 cases (89.79 / 100,000 live birth).

The number of infant deaths in Gunungkidul Regency in 2016 was 61 cases (8/1,000 live birth), while neonates' deaths were 47 cases. Infant mortality is still relatively high when compared to other districts in DIY, although it has exceeded the 2015 National / MDG's target (8 / 1,000 live birth).

The prevalence of iron deficiency anemia in pregnant women in Gunungkidul Regency in 2016 increased to $24.86 \%$ from 2015 which was $21.88 \%$. Health facilities are an input for the ongoing health care system. Health care facilities in Gunungkidul Regency consist of 30 health centers ('puskesmas') and 110 sub-health centers ('puskesmas pembantu' or 'pustu'). From the 30 'puskesmas', 14 of them were health centers with inpatient services and 16 health centers with no inpatient service with normal delivery services.

The visit of outpatient 'Puskesmas' in 2016 was 504,368 visits, down compared to 2015 (602,176 visits). The number of inpatients in 'puskesmas' in 2016 was 7,924 patients, up compared to 2015 (4,422 patients).

Inpatients in health centers in Gunungkidul Regency obtained very little bed utilization data (Bed Occupancy Rate). This does not mean that all puskesmas have small numbers of patients, but there are some inpatient clinics with less than optimal use and there are also 2 health centers hospitalized which under conditions of heavy rehabilitation. Other health care facilities in Gunungkidul Regency consist of 29 medical centers / clinics and 24 individual doctor practices. ${ }^{2}$

The hospital in Gunungkidul currently has five units, consisting of 1 regional general hospital and 4 private hospitals. The total number of beds of the entire hospital is 355. T. The hospital is spread in 3 districts of Gunungkidul Regency, namely:-

1. Karangmojo District: Panti Rahayu Hospital

2. Semanu District: Pelita Husada Hospital and Nurrohmah Hospital

3. Wonosari Subdistrict: Wonosari General Hospital and PKU Muhammadiyah General Hospital Wonosari

In 2016, 42,519 patients were treated and exited both alive and dead, with scattered visits found in Wonosari General Hospital with a Bed Occupancy Rate (BOR) in Wonosari General Hospital of $88 \%$ which exceeded the maximum targeted limit (85\%), while the BOR in Nur Rohmah Hospital is 70\%, PKU Muh Wonosari Hospital is $22.1 \%$, Panti Rahayu Hospital is $46.8 \%$ and Pelita Husada Hospital is $31.1 \%$.

Karangmojo Subdistrict has a number of health facilities such as health centers ('puskesmas'), sub-health centers ('pustu'), Polyclinics, Physicians Practices and Maternity Houses. Health facilities are spread in villages in this sub-district. In detail in 2016, there were 1 hospital in Karangmojo Subdistrict, 2 'puskesmas', 9 'pustu', 2 polyclinics, 7 doctor practices and 5 maternity houses.

Considering that the population in Gunungkidul Regency reaches 704,206 people, this means that if the number of health care beds is calculated by the standard 1 : 1,000 people, ideally Gunungkidul Regency must provide up to 704 beds for patient care. But now, in all public and private health care centers in Gunungkidul, including inpatient health centers, regional and private hospitals, only 450 beds are available. Therefore, Gunungkidul Regency still needs \pm 254 beds. $^{4}$

For Karangmojo sub-district and several areas around the sub-district (Ponjong Subdistrict, Semin and Nglipar Sub-Districts) with a total population of 236,719, only 1 hospital is available, namely the Panti Rahayu Hospital with a capacity of 50 beds, so this area still needs hospitals.

This study analyzed the description of market aspects in the Karangmojo area, Gunungkidul for the plan to establish a Class D Islamic public hospital, and analyzed the financial feasibility of establishing a Class D Islamic hospital with a capacity of 100 beds.

\section{RESEARCH METHOD}

This was a qualitative descriptive study with a case study design. The study consisted of two stages, first examines marketing feasibility using survey methods to assess the market by analyzing data from questionnaires. The second stage examines the feasibility of establishing a General D Class Hospital in the Karangmojo area of Gunungkidul from the financial aspect.

Economic and financial aspects are the core aspects of business planning, because this aspect determines business feasibility in terms of economy and finance. ${ }^{5}$ Discussions conducted in the financial sector concern investment costs, working capital, operating and maintenance costs and possible income calculations. The core of making a feasibility study of a business or project is the market aspect, because market demand for products is the basis for providing products. From this calculation of market demand estimation, then financial analysis can be calculated, include the estimated income as well as the calculation of profit and loss projection. ${ }^{6}$ Therefore in this study, it has taken two aspects, the market aspect and financial aspects.

This study used primary data in the form of survey results using a questionnaire. The selection of respondent samples in this study was carried out by purposive sampling or aiming sample selection. The researcher has a specific goal or target in choosing a sample that is not random, namely the selection of samples based on judgment (judgment sampling), where the sample chosen is the residents around the land that will be built by the hospital as respondents filling in questionnaires, specifically those from 
the 'Yayasan Umat Islam Gunungkidul' (YAUMIG) was chosen based on the possibility of the largest market share of hospitals to be built later, as well as the selection of samples based on quota (quota sampling) that has been determined, which is 100 samples as respondents. ${ }^{-}$As for secondary data obtained from data that has been available in the profile of Gunungkidul Regency. Demographic data of residents of Gunungkidul Regency, socio-economic conditions, competitor conditions and health development plans in Gunungkidul district as market considerations in determining the forecast number of hospital patients to be built. Information about waste requirements and hospital tax is used in calculating initial funds and operating costs.

The instrument used in this study was a questionnaire to obtain primary data, while secondary data obtained from data that has been available in the profile of Gunungkidul Regency. Primary data entered in Microsoft Excel then grouped and processed manually using Microsoft Excel application in the form of a table with an explanation, displayed descriptively a description of market segmentation in this feasibility study. The secondary data is processed quantitatively to determine: 1 . Calculation of initial capital; 2. Measurement of Demand; 3. Estimated Revenue; 4. Estimated operational costs; 5. Calculation of taxes and depreciation fees; 6 . Project the income statement for a period of 10 years; and 7. Investment Assessment using NPV, IRR, PI, PP, ARR and ROI methods..$^{-}$

\section{RESULT AND DISCUSSION}

Judging from the needs of health services, 254 beds are still needed to meet the needs of health services in Gunungkidul. The number of followers of Islam (>96\%) in Gunungkidul district supports the establishment of Islamic hospitals. The survey results of community expectations of the establishment of hospitals in Karangmojo provide an overview of demographic studies, which consider the area and population density as well as the characteristics of the population consisting of age, sex, and marital status. ${ }^{-}$From this information, it can be used as a source for subsequent surveys and forecasting, both qualitative and quantitative so that an estimate of demand can be obtained, then marketing strategies and market share estimation can be determined to calculate income estimation in financial analysis. ${ }^{10}$

The results of the survey conducted by the researcher included the characteristics of respondents including gender, age, marital status, recent education, employment, monthly income, health insurance participation, as well as people's purchasing power towards health services, in the form of first place of treatment, reasons for choosing health services, cost expectations medical treatment, expectations of hospitalization costs, expectation of labor costs, and exploring the problem of doctor services, health care problems and community expectations of health services, to be considered. The following survey results:

The following survey results:

\section{Gender}

Table 1. Sex distribution of respondents

\begin{tabular}{lll}
\hline Gender & Frequency & $\mathbf{\%}$ \\
\hline Male & 36 & 36 \\
Female & 64 & 64 \\
Total & $\mathbf{1 0 0}$ & $\mathbf{1 0 0}$ \\
\hline
\end{tabular}

Based on table 1 , it is known that the majority of respondents were female (64\%).

Age

Table 2. Distribution of age of respondents

\begin{tabular}{llll}
\hline NO & Age of respondents & Frequency & $\mathbf{\%}$ \\
\hline 1 & $<15$ & 1 & 1 \\
2 & $16-19$ & 0 & 0 \\
3 & $20-29$ & 8 & 8 \\
4 & $30-39$ & 27 & 27 \\
5 & $40-49$ & 38 & 38 \\
6 & $>50$ & 26 & 26 \\
& Total & $\mathbf{1 0 0}$ & $\mathbf{1 0 0}$ \\
\hline
\end{tabular}

Based on table 2 it is known that the largest segment in terms of age of respondents is 40-49 years old (38\%). Aged 30-39 years old (27\%) and over 50 years old (29\%). As for the age of less than 15 years, 16-19 years and ages 20-29 years each less than $10 \%$.

\section{Marriage status}

Table 3. Status pernikahan responden

\begin{tabular}{|c|c|c|}
\hline Marriage status & Frequency & $\%$ \\
\hline No / not married & 4 & 4 \\
\hline Married & 96 & 96 \\
\hline
\end{tabular}

Based on table 3 it is known that the largest segment in terms of the marital status of the respondents is Married (96\%).

\section{Education Level}

Based on picture 1. It is known that the largest segment in terms of education level is elementary school (40\%), then junior high school / MTs (30\%). 


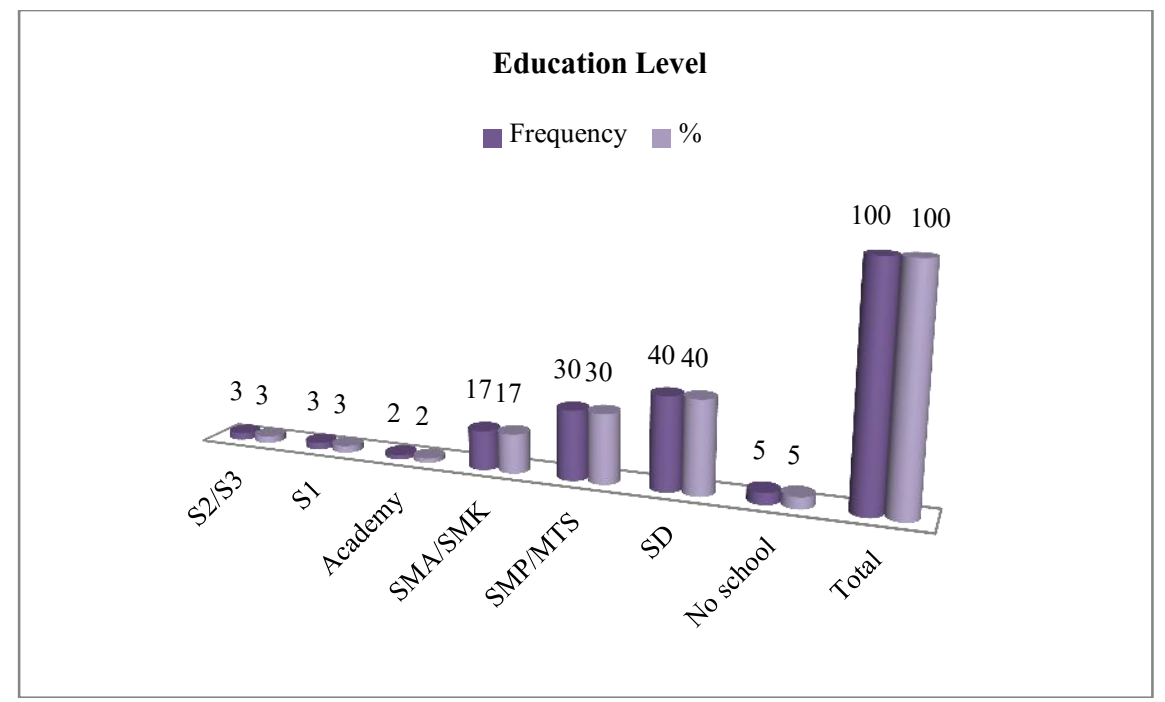

Picture 1. Education Level

\section{Type of work}

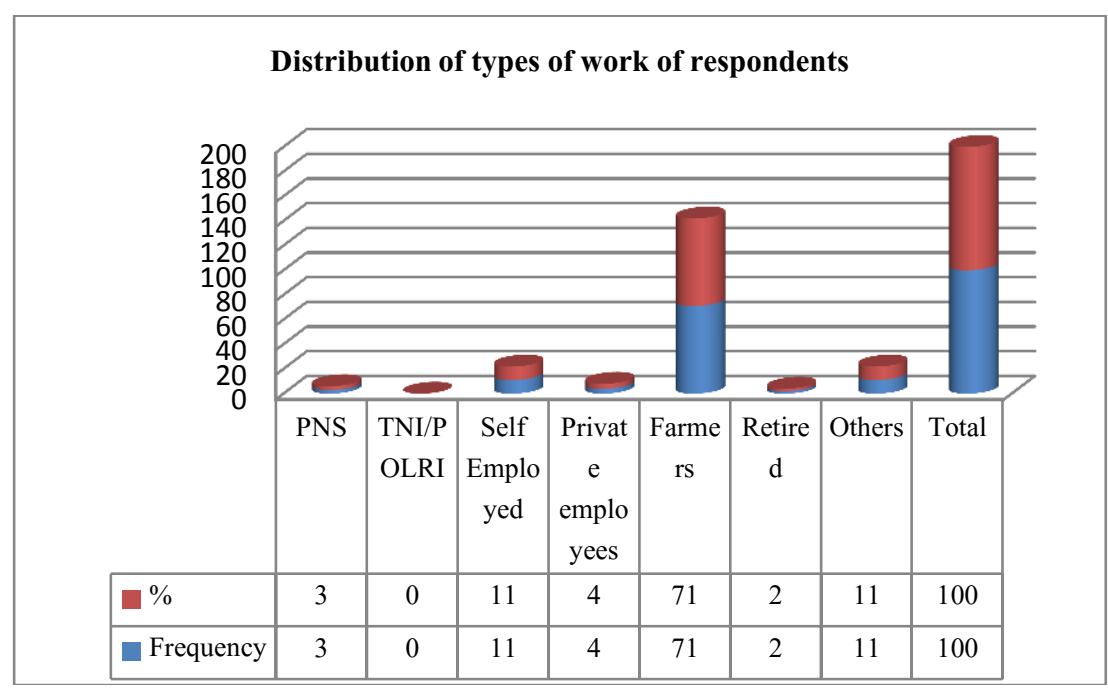

Picture 3. Distribution of types of work of respondents

Based on table 4, it is known that the largest segment in terms of employment of respondents is Farmers (71\%).

\section{Earnings per month}

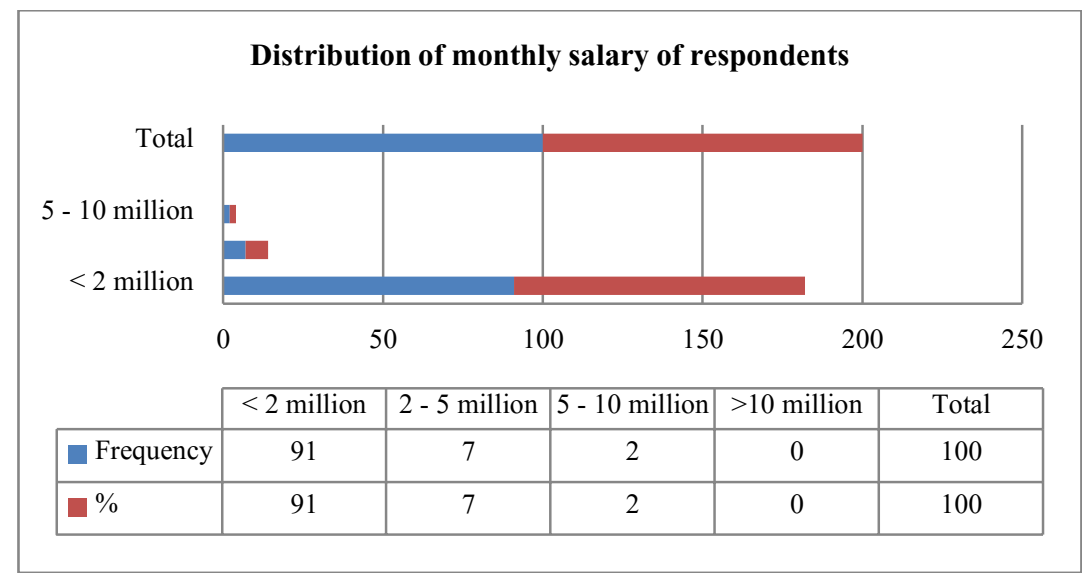


Picture 2. Distribution of monthly salary of respondents

Based on picture 2. It is known that the largest segment in terms of respondents' income is less than 2 million per month (91\%).

\section{Participation in Health Insurance}

Table 4. Distribution of respondents health insurance participants

\begin{tabular}{lll}
\hline Insurance Participation & Frequency & $\mathbf{\%}$ \\
\hline Not an Insurance participant & 20 & 20 \\
Insurance Participant & 80 & 80 \\
Total & $\mathbf{1 0 0}$ & $\mathbf{1 0 0}$ \\
\hline
\end{tabular}

Table 5. Insurance Participants by type

\begin{tabular}{lll}
\hline Type of Insurance & Frequency & $\mathbf{\%}$ \\
\hline Askes/Jamsostek & 12 & 15 \\
Jamkesmas/Jamkesos & 2 & 3 \\
BPJS Kesehatan & 59 & 74 \\
Others & 7 & 9 \\
Total & $\mathbf{8 0}$ & $\mathbf{1 0 0}$ \\
\hline
\end{tabular}

Based on table 5, it is known that the largest segment in terms of ownership of health insurance is having insurance $(80 \%)$, while in table 5 the highest insurance followed is BPJS Kesehatan (74\%).

\section{Chosen first traetment place}

Table 6. Distrivution of Chosen first traetment place of respondents

\begin{tabular}{lll}
\hline Choice of treatment places & Frequency & $\mathbf{\%}$ \\
\hline Practitioner doctor & 16 & 16 \\
Puskesmas & 69 & 69 \\
Clinic/ medical center & 3 & 3 \\
Hospital & 9 & 9 \\
Alternative & 2 & 2 \\
Others & 1 & 1 \\
Total & 100 & 100 \\
\hline
\end{tabular}

Based on table 6 it is known that the largest segment of respondents based on chosen first treatment place is puskesmas (68\%) followed by medical doctors and hospitals.

\section{Reasons for choosing health services}

Table 7. Distribution of reasons for choosing health services of respondents

\begin{tabular}{lll}
\hline $\begin{array}{l}\text { Reasons for choosing health } \\
\text { services }\end{array}$ & Frequency & $\mathbf{\%}$ \\
\hline Close & 17 & 17 \\
There is a favorite doctor & 4 & 4 \\
Good \& fast service & 32 & 32 \\
Islamic service & 34 & 34 \\
Cheap & 12 & 12 \\
Others & 1 & 1 \\
\hline
\end{tabular}

\begin{tabular}{lll}
\hline Total & 100 & 100 \\
\hline
\end{tabular}

Based on table 7, it is known that "Islamic services" are the most common reason given by respondents in choosing favorite hospitals / clinics (34\%), according to the majority of the population who embrace Islam. In addition, respondents chose the place of treatment for good and fast service reasons $(32 \%)$.

\section{Expectation of outpatient costs (general practitioner)}

Based on table 8 it is known that the largest segment of the average cost of treatment for general practitioners is $<$ IDR 50,000 (77\%) and the following is IDR 50,000 (20\%).

Table 8. Distribution of the average cost of medical treatment for general practitioners

\begin{tabular}{lll}
\hline Average outpatient costs (general) & Frequency & $\mathbf{\%}$ \\
\hline$<$ Rp. 50.000 & 77 & 77 \\
Rp50.000-Rp100.000 & 20 & 20 \\
Rp100.000-Rp150.000 & 1 & 1 \\
Rp150.000-Rp200.000 & 0 & 0 \\
$>$ Rp200.000 & 2 & 2 \\
Total & $\mathbf{1 0 0}$ & $\mathbf{1 0 0}$ \\
\hline
\end{tabular}

Expectation of hospitalization cost (for 3 days of treatment without surgery)

Table 9. Distribusi rata-rata biaya rawat inap

\begin{tabular}{lll}
\hline Average cost of hospitalization & Frequency & $\mathbf{\%}$ \\
\hline$<$ Rp1.000.000 & 84 & 84 \\
Rp1.000.000-Rp1.500.000 & 12 & 12 \\
Rp1.500.000-Rp2.000.000 & 3 & 3 \\
Rp2.000.000-Rp3.000.000 & 1 & 1 \\
$>$ Rp3.000.000 & 0 & 0 \\
Total & $\mathbf{1 0 0}$ & $\mathbf{1 0 0}$
\end{tabular}

Based on table 9 it is known that the largest segment of the average cost of hospitalization for three days of treatment (drug costs, inpatient room and all hospital facilities) is $<$ Rp. $1,000,000(84 \%)$

\section{Expecttaion of normal labor cost}

Table 10. Distribusi rata-rata biaya persalinan

\begin{tabular}{ccc}
\hline Average labor cost & Frequency & $\mathbf{\%}$ \\
\hline$<$ Rp1.000.000 & 94 & 94 \\
Rp1.000.000- & 4 & 4 \\
Rp2.000.000 & & \\
Rp2.000.000- & 2 & 2 \\
Rp3.000.000 & & \\
$>$ Rp3.000.000 & 0 & 0 \\
Total & $\mathbf{1 0 0}$ & $\mathbf{1 0 0}$ \\
\hline
\end{tabular}

Based on table 10, it is known that the largest segment of the average delivery cost is $<\mathrm{Rp} 1,000,000$ which is as much as $94 \%$. 


\section{Problems with doctor services}

Table 11. Problems with doctor services

\begin{tabular}{llc}
\hline No & Problems with doctor services & Frequency \% \\
\hline 1. & lack of explanation or & 39 \\
& education & \\
2. & doctors are not friendly & 24 \\
3. & the doctor arrives late & 18 \\
4. & slow doctor services & 16 \\
5. & others & 3 \\
\hline
\end{tabular}

Based on table 11, it is known that the most common medical service problem is that doctors are lacking in providing explanations and education (39\%)

\section{Problems with health services}

Table 12. Problems with health services

\begin{tabular}{lll}
\hline No & Problems with health services & Freaquency $\%$ \\
\hline 1. & Slow hospital services & 33 \\
2. & unfriendly service & 25 \\
3. & expensive rates & 18 \\
4. & Too much requirements that must & 17 \\
& be fulfilled & \\
5. & incomplete info & 4 \\
6. & Others & 2 \\
\hline
\end{tabular}

Based on table 12 it is known that the most common health service problem is slow hospital services (33\%)

\section{Community expectations of hospital services}

Table 13. Community expectations of hospital services

\begin{tabular}{lll}
\hline No & Expectation & Jumlah \% \\
\hline 1. & Islamic service & 31 \\
2. & Fast and Close Service & 38 \\
3. & Affordable rates & 29 \\
4. & Others & 2 \\
\hline
\end{tabular}

Based on table 13, it is known that the community's expectations of the services of Gunungkidul Islamic Hospital are fast and close services, which are 38 respondents $(38 \%)$, Islamic services as many as 31 respondents (31\%), affordable rates (29\%), Market Analysis of the establishment of Islamic general hospitals in the Karangmojo area from an external aspect, that is geographical, has the main market potential of the population in the Karangmojo Gunungkidul District and surrounding areas.

The population for Karangmojo Subdistrict is 56,573 and the area around the Hospital outside Karangmojo Subdistrict is around 236,179 people from Ponjong, Semin and Nglipar Subdistricts which are areas directly adjacent to the Karangmojo sub-district. The demographic, educational, socio-economic and local cultural survey results showed that the majority of respondents were women (64\%) with the highest age distribution between $40-49$ years (38\%), married status $(96 \%)$, last education of elementary school $(40 \%)$, farmer's work (71\%) with monthly income $<2$ million (91\%). The other illustration of economic conditions beside the income, are also explored through the purchasing power of the people, especially on health services described in the results of the questionnaire, hoping the cost of medical treatment for outpatients is $<\mathrm{Rp}$. 50,000 (77\%), the cost of hospitalization (for 3 days of treatment without surgery) $<$ Rp. $1,000,000 \quad(84 \%)$ and normal labor costs $<$ Rp. $1,000,000$ (94\%).

The establishment of a hospital in such a market area will be more appropriate, namely a hospital with sufficient facilities and affordable rates. Considering the types of classification of hospitals, there are class A, B, C and D, the higher the class, the more facilities required, and of course the higher costs needed to establish the hospital and the effect on hospital cost and fees..$^{-1}$ For this reason, the establishment of a general Islamic D class hospital is considered appropriate to the market conditions. ${ }^{12}$

In addition to looking at market characteristics and people's purchasing power, surveys have also been conducted on many problems related to health services, doctor services, as well as community expectations regarding hospitals that will be built. This study shows that community expectations about Islamic services are quite large $(31 \%)$ In addition, the problem of hospital services faced by respondents are slow services (33\%), also related to doctor services, as many as $39 \%$ of respondents felt doctors were lacking in providing explanations or education. Things that affect patient satisfaction include: smooth registration, waiting time, fast, friendly, polite service, good skills and medical care, professional, clean room and complete

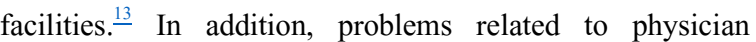
services can be overcome by holding a System-wide relationship-centered communication skills training improved patient satisfaction scores, improved physician empathy, self-efficacy, and reduced physician burnout. ${ }^{14}$

The presence of the Islamic Gunung Kidul Hospital is highly anticipated by the community as a pioneer of Islamic health services, considering that more than $90 \%$ of the residents of Gunungkidul Regency adhere to Islam. However, the weakness in this study was the non-random selection of research samples, so that the results of the analysis had low generalization abilities. The sample taken is from Jama'ah YAUMIG (Gunung Kidul Muslin Community Foundation), where all are adherents of Islam, so the results of the survey of community expectations about high expectations for Islamic services cannot be generalized to all residents in Gunungkidul Regency, especially Karangmojo District. ${ }^{?}$ 
Regarding internal aspects in market analysis, reviewed on health facilities. Considering that the population in Gunungkidul Regency reaches 704,206 residents, but the number of beds has only 450 beds hospitals / inpatient clinics, so 254 beds are still needed. In Karangmojo Subdistrict especially, there is only one D class private hospital with a capacity of 50 beds with a population of about 292.752 people around Karangmojo.

As for financial analysis, to establish a hospital, it is necessary to make a feasibility study, one of which is the study of funding / financial capabilities which include: 1) estimation of the amount of investment fund required and funding sources; 2) estimation of income or income projection on the estimated number of visits and bed occupancy; 3) estimation of fixed and variable costs for the forecast of human resources; 4) cash flow projections of 5 (five) to 10 (ten) years; and 5) profit and loss projection of 5 (five) to 10 (ten) years.

In this study a financial analysis has been conducted which includes:

a. Calculation of Initial Capital (tangible fixed assets + intangible fixed assets + working capital) - assets: (Rp.27,887,806,900 + Rp.1,169,937,200+ Rp.2,214,197,318) - $0=$ Rp.31,271,941,418. Calculation of initial capital includes total tangible assets, intangible assets and working capital. $\frac{15}{}$ This working capital is calculated to cover part of the operational costs in the first and second year, assuming $65 \%$ of the income from the estimated income earned, and then the remaining $35 \%$ is included in the calculation of working capital.

b. Estimated number of patients for a period of 10 years. Estimation of the number of patients for the 10-year period included outpatients (general, emergency room, specialist poly and dental), hospitalization, hemodialysis patients, patient with medical treatments and medical support. The estimated number of these patients uses forecasting techniques with qualitative methods. The qualitative method used was Expert Opinion. Outpatient on the average in the first year was 60 patients and increased by $15 \%$ in the second to sixth year then increased by $10 \%$ every year in the seventh year to the tenth year.

c. Estimated Income. Estimated Income or Income projection is formulated from outpatient, inpatient, motorbike parking, car park and canteen income every year for 10 years. This revenue projection is calculated for 10 years, assuming cooperation with BPJS in the 3rd year. To be able to work with BPJS and to be able to provide professional services, of course hospitals must be accredited according to the Hospital Accreditation Commission (KARS). $\stackrel{16}{ }$ As for supporting Islamic services, accredited hospitals can also be submitted for certification of Sharia Hospital from the Indonesian Islamic Health Effort Assembly (MUKISI) in collaboration with the National Sharia Council of the Indonesian Ulema Council (DSNMUI). $\stackrel{17}{ }$ Plans for hospital submissions for KARS accreditation have been included and planned activities and budgets, which have been included in the estimation of this hospital expenditure in the order of time.

d. Projected operating cost. Estimated operational costs are costs used for employee salaries, medical doctor services, consumption of purchases of office equipment, transportation, telephone, electricity, medicine and consumables and other maintenance costs, along with a percentage increase every year for 10 years, which is adjusted to increase in the number of patients and the increase in employee salaries that have been calculated.

e. Profit and loss projection. Guided by the projected number of patients, the projected income and estimated costs needed for operations, then the estimated profit and loss can be determined as well as the estimated cash flow of the project.

f. Estimated cash flow. The estimated cash flow is calculated based on the sum of net income, depreciation costs plus a tax savings on loan interest, considering that the investment in the construction of this hospital is mostly bank loan funds.

g. Investment valuation. After all financial data are summarized and arranged in the form of project cash flow, an analysis can be carried out to assess whether the proposal or plan is feasible from the financial aspect. This investment assessment is done by method:

1) Net Present Value (NPV). This method is used to measure investment feasibility, where all projected net cash flows in the future must be expressed in the present value which is converted to a factor interest rate or discount. $\frac{18}{\text { If }}$ the NPV is positive, the project is accepted, while if the project's negative NPV is rejected.

2) Internal Rate of Return (IRR). IRR is a discount rate that equates the present value of net cash flow with the present value of investment. This method calculates the interest rate that equates the present value of investment with the present value of net cash receipts in the future. If this interest rate is greater than the relevant interest rate (the required interest rate) then the investment is said to be profitable, but if it is smaller than it is said to be harmful or not feasible.

3) Provitabitity Index (PI). This method calculates the comparison between the present value of net 
cash receipts in the future and the present value of investment. If the Profitability Index (PI) is greater than 1 , then the project can be accepted or profitable, but otherwise if it is less than 1 it is said to be unprofitable.

4) Payback Period (PP). This method measures how long (time period) an investment can return. If the company has determined in advance the maximum payback period required, if it turns out the results of the calculation are shorter than those prescribed, the project is worthy of acceptance, but if it is longer than what has been determined then it is declared not feasible.

5) Acounting Rate of Return (ARR). This technique is used to determine whether a project proposal is feasible or not by comparing the average profit level with the required level of profit. If the ARR value is greater than the required level of profit, then the investment is said to be feasible or profitable. ${ }^{19}$

6) Return of Investment (ROI). ROI (return on investment) is a measure or quantity used to evaluate the efficiency of an investment compared to the costs and initial capital spent. ${ }^{20}$

From the calculation of financial analysis the value obtained is: 1) $\mathrm{NPV}=\mathrm{Rp} .9 .983 .868 .526,00$; 2) $\mathrm{IRR}=$ $12,88 \%$; 3) PI = 1,3193 kali; 4) $\mathrm{PP}=8$ years 4 months; ARR $=10,49 \%$; and ROI $=5 \%$. The sensitivity analysis calculation shows a positive NPV value.

Table 14. Calculation of NPV \& IRR with an interest of 8\% (in Rupiah)

\begin{tabular}{ccc}
\hline Year & Net Cash Flow & Present Value \\
\hline 1 & 2.108 .284 .067 & 1.952 .114 .877 \\
2 & 3.437 .109 .247 & 2.946 .767 .187 \\
3 & 3.129 .397 .661 & 2.484 .216 .759 \\
4 & 4.040 .817 .595 & 2.970 .121 .562 \\
5 & 5.825 .894 .742 & 3.965 .006 .069 \\
6 & 7.203 .063 .882 & 4.539 .152 .079 \\
7 & 9.520 .683 .177 & 5.555 .227 .190 \\
8 & 9.559 .823 .693 & 5.164 .875 .283 \\
9 & 11.905 .033 .383 & 5.955 .480 .654 \\
10 & 12.355 .200 .219 & 5.722 .848 .285 \\
Total Present Value & 41.255 .809 .944 \\
Initial Investment & 31.271 .941 .418 \\
Net Present Value (NPV) & 9.983 .868 .526 \\
Internal Rate of Return (IRR) & $12,88 \%$ \\
\hline
\end{tabular}

From the investment analysis in this study, it was stated that the establishment of class D Islamic public hospitals in Karangmojo, Gunungkidul was feasible or profitable, with the total investment needed in the establishment of 100 beds capacity hospitals was Rp. $31,271,941,418$, -, the time needed to cover operational costs is the 4th year with the remaining operational Rp. $139,958,579$, - and the time needed to achieve BEP or cover initial capital expenditure is 8 years 4 months.

\section{CONCLUSION}

In Karangmojo sub-district, Gunungkidul Regency, establishment of an Islamic hospital with 100 beds is feasible from a review of market aspects. Establishment of Islamic Hospital in Karangmojo is also feasible in terms of financial aspects.

\section{REFFERENCES}

1. BPS, 2015, 'Gunungkidul Dalam Angka 2015', Gunungkidul : Badan Pusat Statisik Kabupaten Gunungkidul.

2. Dinkes, 2016, 'Profil Dinas Kesehatan Kabupaten Gunungkidul Tahun 2016'.

3. Lestari M, 2016, 'Gunungkidul Rencanakan Tambah Rumah Sakit', [Versi Elektronik], Diakses pada 18 April 2017, dari http://www.harianjogja.com/baca/2016/08/09/layanankesehatan-gunungkidul-rencanakan-tambah-rumahsakit-743403

4. Tribunjogja, 2015, 'Gunungkidul Kekurangan 314 Bed Perawatan', [Versi Elektronik], Diakses pada 18 April 2017, dari http://jogja.tribunnews.com/2015/03/12/gunungkidulkekurangan-314-bed-perawatan

5. Manope, Kindangen \& Tawas, 2014, 'Analisa Kelayakan Usaha Komoditas Biji dan Fuli Pala melalui Penilaian Aspek Finansial pada Pedagang Pengumpul "Kios Chandra" di Pulau Siau', Jurnal EMBA, Manado.

6. Hidayati, dkk, 2017, 'Laporan Hasil Studi Kelayakan Bisnis Analisis Keuangan', FEB Universitas Islam Nahdhatul Ulama, Jepara.

7. Indriantoro Nur, M.Sc. \& Supomo Bambang, M.Si., 2002, 'Metodologi Penelitian Bisnis untuk Akuntansi \& Manajemen', BPFE, Yogyakarta

8. Jumingan, 2014, 'Studi Kelayakan Bisnis', Bumi Aksara, Jakarta.

9. Peraturan Menteri Kesehatan Republik Indonesia Nomor 56 Tahun 2014, 'Klasifikasi dan Perizinan Rumah Sakit', 1 September 2014, Berita Negara Republik Indonesia Tahun 2014 Nomor 1221, Jakarta.

10. Musthafa, 2017, 'Manajemen Keuangan', Yogyakarta, Penerbit Andi.

11. Trisnantoro L, 2015, 'Memahami Penggunaan Ilmu Ekonomi Dalam Manajemen Rumah Sakit', Gadjah Mada University Press, Yogyakarta.

12. Dumaris Hotman, 2016, 'Analysis on Tariff Differences Between Hospital's Tariff and INA-CBG's Tariff for Outpatient In Budi Asih Hospital Jakarta on 2015', 
Fakultas Kesehatan Masarakat Universitas Indonesia, Jakarta.

13. Firdaus FF \& Dewi A, 2015, 'Evaluasi Kualitas Pelayanan terhadap Kepuasan Pasien Rawat Jalan Peserta BPJS di Rsud Panembahan Senopati Bantul', Jurnal Medicoeticolegal dan Manajemen Rumah Sakit, Yogyakarta.

14. Boissy, A, et al, 2016, 'Communication Skills Training for Physicians Improves Patient Satisfaction', Society of General Internal Medicine, USA.

15. Hidayah DS \& Pribadi Firman, $n d$, 'Analisis Investasi Peralatan Radiologi di RS PKU Muhammadiyah Yogyakarta Unit 2', MMR UMY, Yogyakarta

16. BPJS Kesehatan, 2019, 'Akreditasi Rumah Sakit Jadi Syarat Wajib Kerjasama dengan BPJS Kesehatan', [Versi Elektronik], Diakses pada 21 Juli 2019, dari https://www.bpjs-kesehatan.go.id/bpjs/post/read/2019 /1019/Akreditasi-Rumah-Sakit-Jadi-Syarat-WajibKerjasama-dengan-BPJS-Kesehatan

17. Mukisi, 2018, 'Sertifikasi Syariah itu Mudah', [Versi Elektronik] https://mukisi.com/1004/sertifikasi-rssyariah-itu-mudah/

18. Parwitasari RD, 2017, 'Studi Kelayakan Pengadaan Alat Picture Archiving and Communication System di RSUP Dr. Soeradji Tirtonegoro Klaten', Jurnal Medicoeticolegal dan Manajemen Rumah Sakit, Yogyakarta

19. Jumingan, 2014, 'Studi Kelayakan Bisnis', Bumi Aksara, Jakarta.

20. Musthafa, 2017, 'Manajemen Keuangan', Penerbit Andi, Yogyakarta. 